\title{
Onion (Allium cepa) Varieties Evaluation at Miyo District of Borana Lowland
}

\author{
Addis Shiferaw* \\ Crop Protection Research Directorate, Oromia Agricultural Research Institute, Ethiopia \\ *Corresponding Author: Addis Shiferaw, Crop Protection Research Directorate, \\ Oromia Agricultural Research Institute, Ethiopia.
}

Received: January 24, 2020

Published: February 13, 2020

(C) All rights are reserved by Addis Shiferaw.

DOI: $10.31080 /$ ASAG.2020.04.0801

\begin{abstract}
Crops can be grown in different agro-ecology depending on their ability to adapt to their specific area. So, it is essential to conduct location specific adaptation trial to identify suitable variety/varieties. Accordingly, an adaptation trial of onion (Allium cepa) varieties was conducted in Miyo district to identify onion varieties that are better in adaptation, yield and other agronomic characteristics, as well aspects and disease tolerance. Four released varieties, viz., Adama red, Melkam, Bombay red and Nasik red were brought from a public research center, Worer Agricultural Research Center, Ethiopia. The four treatments (varieties) were laid out in RCBD with three replications in 2017/2018. The results indicated significant variations between the varieties for the bulb weight and unmarketable yield. However, there was no significant variation among the varieties for all the other parameters. Adama red variety surpassed the other varieties except Nasic red in average bulb weight. Therefore, Adama red can be recommended for the farmers in the area to improve their onion production and productivity.

Keywords: Adaptation; Evaluation; Onion; Variety
\end{abstract}

\section{Introduction}

Onion (Allium cepa) has the major economic and dietary importance in all parts of the world. It is used as spices and condiments for flavoring dishes. Ethiopia has great potential to produce onion [1]. It is comparatively easy to produce provided it is grown in the dry season when diseases are less prevalent using irrigation [2]. It grows between 500 and 2400 ma.s.l., preferring altitude between 700 and 1800 ma.s.l; optimum temperatures from 18.3 to $23.9^{\circ} \mathrm{C}$ day and from 10 to $12^{\circ} \mathrm{C}$ night are ideal for bulb production. It requires sandy loam soil with PH ranging from 5.5 to 6.8 [3]. It doesn't tolerate badly drained soil and it is moderately sensitive to soil salinity [4]. Production system requires the production of health and vigorous seedling in the nursery. Sunken beds prepared for seedling rising at nursery to ensure adequate flooding while watering using watering cane because sunken beds were ability to conserve water in dry lands [5] such as Borana lowland. The frequency of seed bed watering should be every 3 - 4 days. The seedling reaches transplanting at about 45-55 days of sowing when the seedling has 3-4 leaves [7]. Good management on the site is very important to insure high production [8]. Harvesting must be when the pseudo stem soften just above the neck and about half of the plant have their tops down. After onion bulbs are harvested they should be cured for some time before storage or transportation to a long distance. For longer storage life temperature and humidity management in the store is necessary [9]. The market opportunity for onion in the study area is high as demand is high [10]. So onion production is one of the potential income sources for agro-pastoralists and people around the towns. However, successful production depends on the selection of varieties that are adapted to different conditions imposed by specific environment [3]. Hence, the present experiment was conducted to study the response of some improved varieties of common onion using irrigation.

Specific objective

To identify onion varieties that is better in yield and other agronomic characteristics.

\section{Materials and Methods} Description of the study area

The experiment was conducted in Miyo district of Borana zone and it is located south of Addis Ababa at about $732 \mathrm{~km}$. It is characterized by short rainfall. The area is characterized by agro-pastoral production system.

\section{Methodology}

Prior to actual field work, field visits were conducted targeting exploratory study of resources, land use evaluation, production possibilities and identification of the farming system of the concerned zones. Seedlings of four varieties (Adama red, Bombay red, Melkam, Nasic red) were raised on Sunken beds of $1 \mathrm{~m}$ x $5 \mathrm{~m}$ that were prepared at nursery to ensure adequate flooding while watering using watering can. The frequency of seed bed watering was every 3 - 4 days. The seedling reached transplanting at about 45-55 days of sowing when the seedling had 3-4 leaves. The four varieties were transplanted to identify their production capacity and adaptability in the area. The results of the experiment were assessed from agronomic performance point of view. Then, superior ones identified and recommended to use in the respective new potential agro climatic regions. 


\section{Collected data and statistical analysis}

The collected data were planting date, date to emergence of $50 \%$ date to flowering of $50 \%$, harvesting date, harvestable fresh yield (kg/ha), bulb weight, Harvest index, stand count at $100 \%$, plant height at physiological maturity, marketable and unmarketable yield and bulb diameter. Data were analyzed using SAS software and mean separation was done using LSD at 0.05 alpha levels.

\section{Results and Discussion}

The result of analysis of variance shows that there were no significant variations observed among most of the collected param- eters among the varieties tried. Significant variation was observed among the varieties only in average bulb weight and unmarketable yield (Table 1). According to Aklilu [10] finding using the improved cultivars increases the productivity of onion bulbs beside to using recommended amount of fertilizer. Aklilu [10] reported that most of the growers have preferred the Adama variety due to its early maturing and in its anticipation of reduction of production cost than the rest of cultivars. The present finding is in line with the findings of Dinkecha., et al. [11] who reported Adama red gave the highest bulb weight and marketable yield than melkam nasic red and Bombay red varieties.

\begin{tabular}{|l|c|c|c|c|c|c|c|c|}
\hline Source of variation & DF & TBM & YLD (t/1.6m & BULB WT & UNMY (\%) & MY (t/ha) & HI & B Diameter \\
\hline Varieties & 4 & $2.3866^{\text {ns }}$ & $2.380^{\text {ns }}$ & $0.00093^{*}$ & $1.2730^{*}$ & $1.7331^{\text {ns }}$ & $0.00084^{\text {ns }}$ & $11.3326^{\text {ns }}$ \\
\hline Replication & 3 & $14.1918^{*}$ & $12.7633^{*}$ & $0.00059^{\text {ns }}$ & $0.5656^{\text {ns }}$ & $7.9896^{*}$ & $0.001184^{\text {ns }}$ & $9.780^{\text {ns }}$ \\
\hline Error & 6 & 2.0867 & 1.7369 & 0.000261 & 0.31028 & 1.0926 & 0.00134 & 10.738 \\
\hline
\end{tabular}

Table 1: Mean square of total biomass, yield, bulb weight, harvest index, unmarketable yield, marketable yield, and bulb diameter affected by variety and replication.

DF: Degree of Freedom; TBM: Total Biomass; YLD: Total Bulb Yield; UNMY: Unmarketable Yield,

MY: Marketable Yield, BLB WT: Bulb Weight, HI: Harvest index, B Diameter: Bulb Diameter.

There is significant difference among varieties for total biomass, total yield, marketable yield, and harvest index and bulb diameter (Table 2). Bombay red has got significantly higher unmarketable yield than other varieties except Adama red. Adama red has got significantly higher average bulb weight than other varieties except Nasic red (Table 2). This study is in line with other report [12], in which the Adama red variety was the most widely grown variety under irrigation in the country due to its higher bulb yield than Bombay red.
The highest bulb yield (8.43) found in Adama red while lowest (4.91.9) in Melkam. The highest bulb weight (0.1192) found in Adama red while lowest (0.804) in melkam, the highest marketable yield (7.535) found in Nasis red while lowest (5.901) in Bombay red. As compared to Melkam and Bombay red varieties in highest bulb yield, weight and lower unmarketable yield Adama red variety was significantly higher as observed on the table 2 .

\begin{tabular}{|l|c|c|c|c|c|c|c|}
\hline Varieties & TBM & YLD (t/1.6m & BULB WT & UNMY (\%) & MY (t/ha) & HI & B Diameter \\
\hline Adama red & 9.294 & 8.434 & $0.1192^{\mathrm{a}}$ & $0.898^{\mathrm{ab}}$ & 7.535 & 0.908 & 57.05 \\
\hline Bombey red & 8.429 & 7.766 & $0.0833^{\mathrm{b}}$ & $1.864^{\mathrm{a}}$ & 5.901 & 0.918 & 54.68 \\
\hline Melkam & 4.912 & 7.012 & $0.0804^{\mathrm{b}}$ & $0.528^{\mathrm{b}}$ & 6.48 & 0.881 & 55.87 \\
\hline Nasic red & 7.173 & 6.386 & $0.0927^{\mathrm{ab}}$ & $0.441^{\mathrm{b}}$ & 5.944 & 0.891 & 52.49 \\
\hline LSD 5\% & NS & NS & 0.0323 & 1.112 & NS & NS & NS \\
\hline
\end{tabular}

Table 2: Mean values of total biomass, yield, and bulb weight, unmarketable weight, marketable yield, harvest index, bulb diameter affected by varieties.

TBM: Total Biomass; YLD: Total Yield; UNMY: Unmarketable Yield; MY: Marketable Yield; BLB WT: Bulb Weight; HI: Harvest Index; B Diameter: Bulb Diameter

Generally maximum bulb yield and bulb quality (bulb weight, marketable yield and bulb yield) were obtained from Adama reds compared to the rest three varieties, and this variety was not affected by major onion diseases. But, on the rest varieties slightly some onion diseases were seen even though didn't have significant effect on the yield or they are not susceptible to disease. Therefore, it is recommended that Adama red variety is suitable for using in Miyo district. This variety was also selected by pastoral research group (PRG) and field day participant in terms of both yield and no sign of disease observation on this variety [13].

\section{Conclusion and Recommendation}

Onion is one of the popular crops used for commercial and household consumption in the area. Since there are no improved technologies used by the farmers in the area, the finding of our study can contribute to better utilization of the crop. As such the income generated by producing the crop would improve the livelihood of the agro pastoral community. So it is important to introduce new and improved varieties that can adapt to the area to improve the productivity of the farmers or agro-pastoral communities. 
Adama red was found to be significantly greater than other varieties except Nasic red in average bulb weight. It also has the highest yield $(\mathrm{kg} / \mathrm{ha})$ than other varieties tried even though the difference is not significant. Therefore, Adama red can be recommended for the farmers/agro-pastoral communities in the area to improve their onion production and productivity, which has a positive implication on the improvement of their livelihood.

\section{Acknowledgements}

I am grateful to anonymous reviewers for their insightful comments that helped to improve an earlier version of this paper.

\section{Bibliography}

1. CSA (Central statistical Agency). "Agriculture sample survey, Central statistical Agency, Addis Ababa, Ethiopia”. Bulletin 1 (2006): 361.

2. Aklilu L. "Onion research and production in Ethiopia". Actahortic 433 (1997): 95-98.

3. Brewester JL. "Onion and Other Vegetable Alliums". CAB International, Wallingford, UK (1994): 236.

4. Fisseha G. The effects of alternative sources of organic fertilizers in increasing the yield of onions (Allium cepa L.). A M.Sc. Thesis presented to School of Graduate Studies of Addis Ababa University, Ethiopia (1983): 30-70.

5. Eimhoit S., et al. "Soil aggregation - a matter of proper management". Danish Research Centre for Organic Farming (2005).

6. Fekadu M and Dandena G. "Review of the status of vegetable crops production and marketing in Ethiopia". Uganda Journal of Agricultural sciences 12 (2006): 26-30.

7. Muhammad A., et al. "Response of Onion (Allium cepa L.) to Irrigation Intervals and Plant Density in Zuru, Northern Guinea Savanna of Nigeria". Nigerian Journal of Basic and Applied Sciences 19 (2011): 241-247.

8. Steer BT. "The bulbing response to day length and temperature of some Australian cultivars of onion (Allium cepa L)". Australian Journal of Agricultural Research 31 (1980): 511-518.

9. Gubb IR and Tavis MSH. "Onion pre-harvest and postharvest considerations". In: Rabinowitch, H.D., and Currah, L. (eds.). Allim Crop Science. CABI publishing, UK (2002).

10. Aklilu S. "Onion research and production in Ethiopia”. In International Symposium on Edible Alliaceae 433 (1994): 95-98.

11. Dinkecha K., et al. "Determination of Nutritional Profile and Physicochemical Properties of Improved Onion (Allium cepa L.) Varieties in Ethiopia”. Science Publishing Group (2017).

12. Nikus $\mathrm{O}$ and Mulugeta F. "Onion seed production techniques". A manual for extension agents and seed producers, Asella, Ethiopia (2013): 1.
13. Dessalegne L and Aklilu S. "Research Experiences in Onion production”. Research Report No. 55. Ethiopia Agricultural Research Organization, Addis Ababa, Ethiopia (2003).

\section{Assets from publication with us}

- Prompt Acknowledgement after receiving the article

- Thorough Double blinded peer review

- Rapid Publication

- Issue of Publication Certificate

- High visibility of your Published work

Website: www.actascientific.com/

Submit Article: www.actascientific.com/submission.php Email us: editor@actascientific.com

Contact us: +919182824667 